\title{
The Economic Burden of Water Related Infections in the Bamenda Health District: The Case of Diarrhoea
}

\author{
Chenjoh Joseph Nde ${ }^{1, *}$, Ndong Ignatius Cheng ${ }^{1}$, Johannes Tabi Atemnkeng ${ }^{1,2}$, Wilfred Mbacham ${ }^{1,3}$ \\ ${ }^{1}$ Department of Health Economics, Policy and Management, Catholic University of Cameroon, Cameroon \\ ${ }^{2}$ Higher Technical Teacher's Training College Kumba, The University of Buea, Cameroon \\ ${ }^{3}$ Department of Biochemistry and Physiology, Faculty of Medicine and Biomedical Sciences and the Biotechnological Centre, \\ University of Yaounde I, Cameroon
}

Copyright $\bigcirc 2017$ by authors, all rights reserved. Authors agree that this article remains permanently open access under the terms of the Creative Commons Attribution License 4.0 International License

\begin{abstract}
Diarrhoea remains a major public health concern of our times with bad drinking water and frequent poor disposal of human waste matter. Caused by a variety of conditions, it spans from diarrhoea which are of viral bacterial to sometimes metal intoxication. In Cameroon, it is one of the 10 major causes of illness. To assess the burden and lost income due to diarrhoea, the study quantified how much households in the Bamenda Health District (BHD), North West Region (NWR) of Cameroon are losing because of the incidence of diarrhoea related infections. A cluster sampling technique was used to select 8 Public Integrated Health Centres in 8 Health Areas, with an estimated population of about 189,730 people. Data for all reported diarrhoea cases for 2011 and 2012 was collected from the Health Centres. The Cost of Illness (CoI) methodology was used to quantify the direct and indirect cost of diarrhoea infections. It was estimated that about USD22, 361 and USD37, 198 was lost by households in general in 2011 and 2012 respectively. The economic burden over the two years was estimated at USD53, 602.3. If this amount were projected over 10 years it will imply that about USD260, 000 will be lost to the treatment of diarrhoea infections.
\end{abstract}

Keywords Bamenda, Cost of Illness, Diarrhoea, Households, Water

\section{Introduction}

Africa still lags behind the rest of the world with $40 \%$ of her population without access to an improved water supply and sanitation [1]. Diarrhoeal disease accounts for an estimated $4.1 \%$ of the total DALY (Disability Adjusted Life Years) global burden of disease with $88 \%$ of this burden attributed to unsafe water supply, sanitation and hygiene [2]. In Cameroon, the population without access to safe drinking water was $49.5 \%(86.2 \%$ in urban and $31.3 \%$ in rural areas) in 2001 and increased to $57 \%$ in 2005 . The population with improved sanitation was $43 \%$ in 2001 [3, 4]. The UNDP observed that in 2001 the rural population with access to safe drinking water was $50.5 \%$ against $44.2 \%$ in 1996 . From 2005 to 2006 the rate of access to potable water increased by $27.8 \%$ with urban areas being better served (increase of $10 \%$ ) than rural areas (5\% increase). The progress is partly accounted for by the rehabilitation of many bore holes in the Northern part of Cameroon and the construction of new wells using debt recovery funds $[5,4]$. For many people with vulnerable livelihoods, the daily problems associated with access to portable water seriously deplete energy, health, money and time. Inequalities based on wealth and location together with flawed policies, mean that poor people pay the most for and travel the furthest for water [6]. In Cameroon households respond to water shortage by storing water in large containers, but this creates new risks of contamination and breeding sites for the mosquitoes that transmit malaria [7, 6]. A vast majority are compelled to turn to alternative sources such as springs, wells and streams whose bacteriological quality is compromised by their proximity to sources of pollution [8]. Water-related diseases are very common in Cameroon, and this affects children particularly who cannot maintain proper hygienic conditions. One of the main causes of death in children under 5 is diarrhoea alongside malaria and measles [9]. The incidence of diarrhoeal diseases varies greatly with the seasons and age with the incidence being highest in the first two years of life [10]. The objective therefore of this study was to determine the economic burden of water related infections with focus on diarrhoea related infections in the Bamenda Health District.

\section{Methods}

\subsection{Study Site}

Cameroon is situated in West Africa with a population of 
about 21 million inhabitants. About $15.9 \%$ of the population is comprised of children less than 5 years while about $50 \%$ of the population is made up of youths younger than 18 years [11]. The North-West Region (NWR) is one of Cameroon's ten administrative regions with an estimated population of about 1,851,617 inhabitants and an average household size of about 6.88persons [12]. In the region, the under-five mortality stands at 52 per thousand, with mortality due to diarrhoea for under-fives at 5 per thousand [13]. The Bamenda Health District is one of 19 health districts of the NWR and has 17 health areas with a population of 351,730 inhabitants.-Randomised cluster sampling was used in selecting state owned Integrated Health Centres for the study. The health district was broken into four clusters with natural boundaries and hills separating the clusters: Cluster 1 Bamenda I Sub-division; Cluster 2 - Bamenda II Urban; Cluster 3 - Bamenda II Rural; Cluster 4 - Bamenda III Sub-Division. Public Integrated Health Centres in each cluster were identified and two IHC were randomly selected. Bamenda I \& II had just one Integrated Health Centre, so a third IHC each was selected for the Bamenda II Urban and Bamenda II Rural clusters (see map Appendix I).

Table 1. List of Health Areas and Health Centres Randomly Chosen for the Study

\begin{tabular}{|c|c|c|}
\hline Cluster & Health Area & Health Facility \\
\hline \multirow{3}{*}{$\begin{array}{c}\text { Bamenda II } \\
\text { Urban }\end{array}$} & Atuakom & Atuakom Integrated Health Centre \\
\cline { 2 - 3 } & Azire & Azire Integrated Health Centre \\
\cline { 2 - 3 } & Mulang & Mulang Integrated Health Centre \\
\hline \multirow{2}{*}{$\begin{array}{c}\text { Bamenda II } \\
\text { Rural }\end{array}$} & Mbachongwa & $\begin{array}{c}\text { Mbachongwa Integrated Health } \\
\text { Centre }\end{array}$ \\
\cline { 2 - 3 } & Ntankah & Ntankah Integrated health Centre \\
\cline { 2 - 3 } & Akumlam & Akumlam Integrated Health Centre \\
\hline $\begin{array}{c}\text { Bamenda I } \\
\text { Sub-division }\end{array}$ & Nkwen Rural & $\begin{array}{c}\text { Nkwen Rural Integrated Health } \\
\text { Centre }\end{array}$ \\
\hline $\begin{array}{c}\text { BamendaIII } \\
\text { Subdivision }\end{array}$ & Bamendankwe & $\begin{array}{c}\text { Mendankwe Integrated Health } \\
\text { Centre }\end{array}$ \\
\hline
\end{tabular}

\subsection{Cost Calculations}

Table 2. How the Cost of Illness method was applied to the study

\begin{tabular}{|c|c|c|}
\hline $\begin{array}{l}\text { Time } \\
\text { frame }\end{array}$ & & 011 to 2012 (2 years) \\
\hline \multirow{2}{*}{$\begin{array}{c}\text { Unit of } \\
\text { analysis }\end{array}$} & \multicolumn{2}{|c|}{ All new cases of diarrhoea in 2011} \\
\hline & \multicolumn{2}{|c|}{ All new cases of diarrhoea in 2012} \\
\hline \multirow[t]{2}{*}{ Direct costs } & \multicolumn{2}{|c|}{$\begin{array}{c}\text { Personal medical cost - consultation, laboratory } \\
\text { diagnosis, cost of drugs }\end{array}$} \\
\hline & \multicolumn{2}{|c|}{ Personal non-medical cost - transportation } \\
\hline \multirow{4}{*}{$\begin{array}{c}\text { Indirect } \\
\text { costs }\end{array}$} & \multirow{3}{*}{ Lost income } & Due to mortality \\
\hline & & Due to disability and care seeking \\
\hline & & Other \\
\hline & \multicolumn{2}{|r|}{ Non-personal costs } \\
\hline
\end{tabular}

Data on all reported new cases of diarrhoea for 2011 and 2012 were collected directly from the health centre's consultation registers and analysed with the SPSS version 16.0 software. The cost of illness distinguished between direct and indirect costs [14]. Direct costs were visible costs and included transportation, consultation, laboratory examination, cost of drugs attending to the health condition, associated with diagnosis, treatment and care. Indirect costs were those associated with lost productivity and income owing to a diarrhoea episode. The cost of pain and suffering were not included in this study because of the difficulty of placing a monetary value on them.

Using the methods proposed by Hutton and Haller [12] we calculated the total economic cost of diarrhoea infections in 3 steps:

\section{Step I: Direct Cost of Diarrhoea Treatment}

\section{Transport Costs (C1)}

There are principally two main means of public transportation in the Bamenda Health District: motor bikes and urban taxis. Bikes are more accessible since they penetrate the quarters and have the advantage of reaching the most inaccessible areas of a neighbourhood. In order to facilitate our analysis, we assumed that whether a patient used a bike or a taxi as a means of transportation the rates charged for a drop are the same. The assumed charge per drop is summarized on Table 3 below:

Table 3. Estimated transport fare according to distance covered

\begin{tabular}{|c|c|c|}
\hline $\begin{array}{c}\text { Distance from health } \\
\text { facility (in kilometers) }\end{array}$ & $\begin{array}{c}\text { Unit cost per } \\
\text { drop }\end{array}$ & $\begin{array}{c}\text { Total Cost round } \\
\text { trip }\end{array}$ \\
\hline$<1 \mathrm{~km}$ & $0.4 \mathrm{USD}$ & $0.8 \mathrm{USD}$ \\
\hline $1 \mathrm{~km}-2 \mathrm{~km}$ & $0.6 \mathrm{USD}$ & $1.2 \mathrm{USD}$ \\
\hline$>2 \mathrm{~km}$ & $0.8 \mathrm{USD}$ & $1.6 \mathrm{USD}$ \\
\hline Any other & $\begin{array}{c}0.8 \mathrm{USD} \text { per } \\
\text { kilometer }\end{array}$ \\
\hline
\end{tabular}

The total transport cost per health facility was calculated using the following formula:

$$
\mathrm{C}_{1}=\sum_{x=1}^{n} C x N x
$$

Where:

- $\mathrm{C}_{1}$ - transport cost per health facility

- $\mathrm{Cx}$ - transport fare from neighbourhood $\mathrm{x}$ to the health facility and back

- $\mathrm{Nx}$ - number of patients from neighbourhood $\mathrm{x}$

Cost of Consultation (C2)

The cost of consultation in public health centres is same for all the health facilities and stands at USD0.4. The total cost incurred by patients for consultation was calculated as follows:

$$
\mathrm{C}_{2}=\sum_{i=0}^{n} N P
$$

Where:

$\mathrm{C}_{2}=$ cost of consultation

$\mathrm{N}=$ number of patients who consulted per health facility

$\mathrm{P}=$ price of consultation

Cost of Laboratory Tests (C3)

The costs of laboratory examinations differ from one 
health facility to another depending on where they buy their reagents and other factors. Costs of laboratory tests were obtained from the pharmacy of the IHC. For each health facility, we multiplied the number of patients who were asked to take a particular test by the cost of the test to get the total expenditure that was incurred by patients for that test. The cost incurred by diarrhoea patients for each lab test in each of the health facilities was calculated using the formula below:

$$
\mathrm{Cy}=\sum_{i=1}^{8} \mathrm{CtiNi}
$$

Where:

$C_{y}$ - cost of each test where $y=$ type of test

Cti - Cost of test per health facility where $\mathrm{i}=$ health facilities with $i=1,2,3 \ldots 8$

$\mathrm{Ni}$ - number of patients who under took the test per health facility

\section{Cost of Drugs (C4)}

The cost of drugs used in treating diarrhoea was obtained from the price list of the North West Special Fund for Health Promotion. All doses where gotten from the British National Formulary [16]. For us to estimate how much a patient spent on drugs, we determined the dosage and from the dosage we are able to know the quantity of drugs the patients is supposed to consume in order to complete his/her treatment. Then we multiplied the quantity by the unit price to know the total amount of money spent by a patient on a drug.

The total direct cost of diarrhoea was given by the formula:

$$
\mathrm{TDC}=\mathrm{C}_{1}+\mathrm{C}_{2}+\mathrm{C}_{3}+\mathrm{C}_{4}
$$

Where TDC - total direct cost

Step II: Indirect Cost

Lost Activity Days

We determined the number of activity days lost per age group as a result of diarrhoea related infections following steps put forward in Hutton and Haller [1]. According to Hutton and Haller [15], lost activity days due to diarrhoea infections were estimated as shown on Table 4 below:

Table 4. Estimation of lost activity days per age group

\begin{tabular}{|c|c|c|}
\hline AGE GROUP & $\begin{array}{c}\text { VARIABLES and } \\
\text { SOURCE }\end{array}$ & $\begin{array}{c}\text { AVERAGE LOST } \\
\text { ACTIVITY DAYS }\end{array}$ \\
\hline $\begin{array}{c}\text { Non-school age } \\
\text { kids (<5years) }\end{array}$ & $\begin{array}{c}\text { Average of 6.2days for } \\
\text { breast fed infants and 3.8 } \\
\text { days for formula fed } \\
\text { infants [9] }\end{array}$ & 5 days \\
\hline School age kids & 3 days [9] & 3 days \\
\hline $\begin{array}{c}\text { Working age } \\
\text { group }\end{array}$ & 2 days [9] & 2 days \\
\hline
\end{tabular}

Value of Time

In the absence of an alternative means of valuation, we assumed that a day of lost activity is equal to the Gross National Income per capita per day (GNI per capita per day) for the year in question. This is a further development from Hutton et. al, [9] where just the GNI per capita was used. For children of non-school age, we will estimate the value of their Lost Activity Day at $100 \%$ of the GNI per capita per day. This is because a parent or carer will have to give up his/her activities in order to take care of the sick child for as long as the child is sick or hire a carer for the child. This is contrary to what is proposed in Hutton et al. [9], where the lost activity per day for non-school age children is valued at $50 \%$ of GNI per capita. We choose to value the Lost Activity Day for children less than 5 years at $100 \%$ of the GNI per capita per day because in Cameroon children begin schooling at an early age (at 1 year or less for those that go to "Day Care Institutions" and 2 years or less for those that attend pre-nursery and nursery schools). In addition, informal learning takes place at home for children who do not go to a formal school before the age of five. This informal learning equally contributes in the development of the child. This is supported by O'Neill [17] who emphasises that education encompasses all aspects of life and can happen in any situation and at any age either alone or with others. For children of school age and adults, we also value their last activity day at $100 \%$ of the GNI per capita per day.

\section{Total Indirect Cost (TIC)}

The total indirect cost was calculated as follows:

$$
\mathrm{TIC}=\sum_{g=1}^{3} V g N g
$$

Where:

$\mathrm{g}-$ age group where $1=<5$ years, $2=$ school age kids, $3=$ adults

$\mathrm{Vg}$ - Value of Lost activity days per age group

$\mathrm{Ng}$ - number of diarrhoea patients per age group.

Step III: Total Economic Cost of Diarrhoea

The total economic cost of diarrhoea related infections was calculated by adding the total direct cost to the total indirect cost as shown below:

$$
\mathrm{TEC}=\mathrm{TDC}+\mathrm{TIC}
$$

Where TEC - total economic cost, TDC - total direct cost, TIC - total indirect cost

With the above, we were able to arrive at a quantification and thorough analysis of the economic burden of diarrhoea related infections in the Bamenda Health District.

\section{Results}

\subsection{Frequency of Diarrhoea Infections per Health Facility}

Data was collected from 8 public Integrated Health centres randomly chosen from amongst the 12 public Integrated Health facilities that are found in the Bamenda Health District. The number of cases reported at the various health facilities for 2011/2012, are presented on Table 5 below. As shown, a great majority of diarrhoea infections within each IHC occurred in 2012. 
Table 5. Distribution of cases according to health facilities for 2011 and 2012

\begin{tabular}{|c|c|c|c|c|c|c|}
\hline \multirow[b]{2}{*}{ IHC } & \multicolumn{2}{|c|}{2011} & \multicolumn{2}{|c|}{2012} & \multirow[b]{2}{*}{ TOTAL } & \multirow[b]{2}{*}{ Percentage (\%) } \\
\hline & $\begin{array}{c}\text { Number of } \\
\text { cases }\end{array}$ & \% within IHC & Number of cases & $\%$ within IHC & & \\
\hline Atuakum & 100 & $45 \%$ & 122 & $55 \%$ & 222 & 11.6 \\
\hline Azire & 238 & $33 \%$ & 484 & $67 \%$ & 722 & 37.6 \\
\hline Mulang & 82 & $31.3 \%$ & 180 & $68.7 \%$ & 262 & 13.7 \\
\hline Ntankah & 3 & $3.1 \%$ & 94 & $96.9 \%$ & 97 & 5.1 \\
\hline Akumlam & 35 & $60.3 \%$ & 23 & $39.7 \%$ & 58 & 3 \\
\hline Mbachongwa & 68 & $48.6 \%$ & 72 & $51.4 \%$ & 140 & 7.3 \\
\hline Mendankwe & 98 & $67.6 \%$ & 47 & $32.4 \%$ & 145 & 7.6 \\
\hline Nkwen & 116 & $42.5 \%$ & 157 & $57.5 \%$ & 273 & 14.2 \\
\hline Total & 740 & $38.6 \%$ & 1179 & $61.4 \%$ & 1919 & 100 \\
\hline
\end{tabular}

\subsection{Age Distribution of Diarrhoea Cases}

The age distribution of the patients is presented on Table 6 below:

Table 6. Age distribution of diarrhoea patients

\begin{tabular}{|c|c|c|c|c|c|c|c|}
\hline \multirow[b]{2}{*}{ YEAR } & \multicolumn{6}{|c|}{ AGE } & \multirow[b]{2}{*}{ TOTAL } \\
\hline & Missing & $<11$ Months & 1-4 Years & 5-14 Years & $\begin{array}{c}15-64 \\
\text { Years }\end{array}$ & $>64$ Years & \\
\hline Total cases & 13 & 290 & 601 & 262 & 677 & 76 & 1919 \\
\hline$\%$ of Total & $0.7 \%$ & $15.1 \%$ & $31.3 \%$ & $13.7 \%$ & $35.3 \%$ & $4.0 \%$ & \\
\hline
\end{tabular}

From the above table, children aged 0 to 4 years suffered more significantly from diarrhoea infections with 904 cases $(47.1 \%)$ reported in the study period. Within this group, children aged $1-4$ years suffered most with 601 recorded cases representing $31.1 \%$ of diarrhoea infections.

\subsection{Estimating the Direct Cost of Diarrhoea Infections}

The cost incurred by diarrhoea patients for transport, consultation, laboratory tests, and prescribed drugs is shown on Table 7 below:

Table 7. The direct cost of diarrhoea infections

\begin{tabular}{|c|c|c|c|}
\hline \multirow{2}{*}{ Description } & \multicolumn{2}{|c|}{ Direct Cost } & Total \\
\cline { 2 - 4 } & 2011 Cost & 2012 Cost & 1723 USD \\
\hline Transport cost & 624.6 USD & 1098.4 USD & 767.6 USD \\
\hline Consultation & 296 USD & 471.6 USD & 5729.1 USD \\
\hline Lab & 2350 USD & 3379.1 USD & 3907 USD \\
\hline Drugs & 1592.7 USD & 2314.3 USD & $\mathbf{1 2 , 1 2 6 . 7 U S D}$ \\
\hline Total & $\mathbf{4 8 6 3 . 3 U S D}$ & $\mathbf{7 2 6 3 . 4 U S D}$ & \\
\hline
\end{tabular}

\subsection{Estimating the Indirect Cost of Diarrhoea Infections}

The indirect cost of diarrhoea infections for the Bamenda Health District is shown on Table 8 below:

Table 8. The indirect cost of diarrhoea infections

\begin{tabular}{|c|c|c|c|}
\hline \multicolumn{3}{|c|}{ Indirect cost } \\
\hline Income & 2011 & 2012 & Total \\
\hline Lost income & $15,261.1$ USD & $26,214.5$ USD & $41,475.6$ USD \\
\hline
\end{tabular}




\section{Discussion}

The total direct cost (4) of treating diarrhoea is estimated at USD12, 126.7 while the total indirect cost (5) stands at USD41, 475.6 for the study period. This gave a total cost (6) of USD53, 602.3. A greater proportion of the total economic burden of diarrhoea infections is attributed to the indirect cost or opportunity cost which accounts for $77.38 \%$ of the total cost while the direct cost accounts just for $22.62 \%$. This cost of diarrhoea infections seems high and adds to the pain, anxiety, discomfort, and suffering patients and their care givers experience. If we were to quantify these variables, then the total economic burden of diarrhoea would be by far higher than the present value. In 2011, 740 cases were recorded while in 2012, 1179 cases were recorded implying a $22.8 \%$ increase in the rate of diarrhoea infections in 2012 .i.e. four hundred and thirty-nine (439) more cases were recorded in 2012. The increase in diarrhoea related infections between 2011 and 2012 could be attributed to the fact that the water infrastructure in the Bamenda Health District was not expanding as fast as the rate of population growth in the area. Consequently, there was a sustained shortage in water supply which forced households to resort to water sources that were prone to different forms of contamination. With a total expenditure of about USD53, 602.3 spent by the households of 1919 patients, it implies that for each patient/household, the Bamenda Health District economy lost averagely about USD28 to the treatment of diarrhoea related infections. This figure is significant for households in Cameroon given that according to the most recent Human Development Report (HDR) [18] an average Cameroonian lives on about US\$ 2 per day. Already victims of very low incomes, such a compelling expenditure on households in the Bamenda Health District will mean the consumption of some basic commodities will have to be forgone in order to meet up with the increase in health care expenditures caused by diarrhoea infections. This is in line with WHO [19] which says that the impact of ill health on households can be measured in terms of the impact it has on the consumption of non-health goods and services. In Cameroon where most health care expenditures are out of pocket, the situation is aggravated by the fact that while health care expenditures are rising, the time spent seeking care or in the state of ill health reduces the time spent on productive activities that would provide income for the household. The future income of the household will equally be affected if the household resorts to borrowing in order to meet up with the sudden health care expenditure caused by diarrhoeal infections. The cumulative activity days lost due to diarrhoea episodes, even makes the situation worse. For children of school age a cumulative total of 258 school days were lost in 2011 while for 2012 a cumulative total of 528 school days are lost. The OECD [20] emphasizes that proper schooling is very important for the future productivity and overall welfare of a community. This therefore implies that for children of school age within the Bamenda Health District, who miss about 393 school days averagely, the effect on future productivity and welfare of the community will be enormous. A look at the number of cumulative activity days lost by persons of the working age group (634 days in 2011 and 872 days in 2012) reveals that a lot of income was also lost by households within the Bamenda Health District due to diarrhoeal diseases and this greatly affects the overall economic productivity of the area.

Our findings have implications for future perspectives in the fight against or prevention of diarrhoea infections. Our study focused only on 8 public integrated health centres in a Health District that has more than 35 health facilities both public and confessional. This implies that, a study that includes all health facilities within the health district will most likely reveal a better picture of the economic burden of diarrhoea infections on households. Studies equally need to be done to understand the care seeking behaviour of parents and care givers when faced with a diarrhoea episode especially for under-fives in order to understand the prevention strategies that can be put in place. As the portable water supply becomes irregular communities and councils have to be more proactive and take measures to have their own parallel water supply. Equally basic hygiene and sanitation rules need to be enforced in homes and schools in order to curb the number of school days lost to diarrhoea infections. Recently, the government introduced free malaria treatment for children less than 5 years old, if diarrhoea continues to have such an impact on children less than five and on households then the government should think of making diarrhoea treatment free for children less than five years.

\section{Conclusions}

The age based hospital attendance revealed that majority of the patients who suffered from diarrhoea infections where children less than 5 years old. For children of school age a cumulative total of 258 school days were lost in 2011 while a cumulative total of 528 school days are lost in 2012. For persons of the working age group 634 days in 2011 and 872 days in 2012. The cumulative Total economic burden of diarrhoea infections for 2011 \& 2012 was estimated at USD53, 602.3. This implies that over the two years, averagely about USD26, 801 was lost to diarrhoea infections. If this amount is projected over the next 10 years, about USD260, 801 would be lost by households in the Bamenda Health District to diarrhoea infections. 


\section{Appendix}

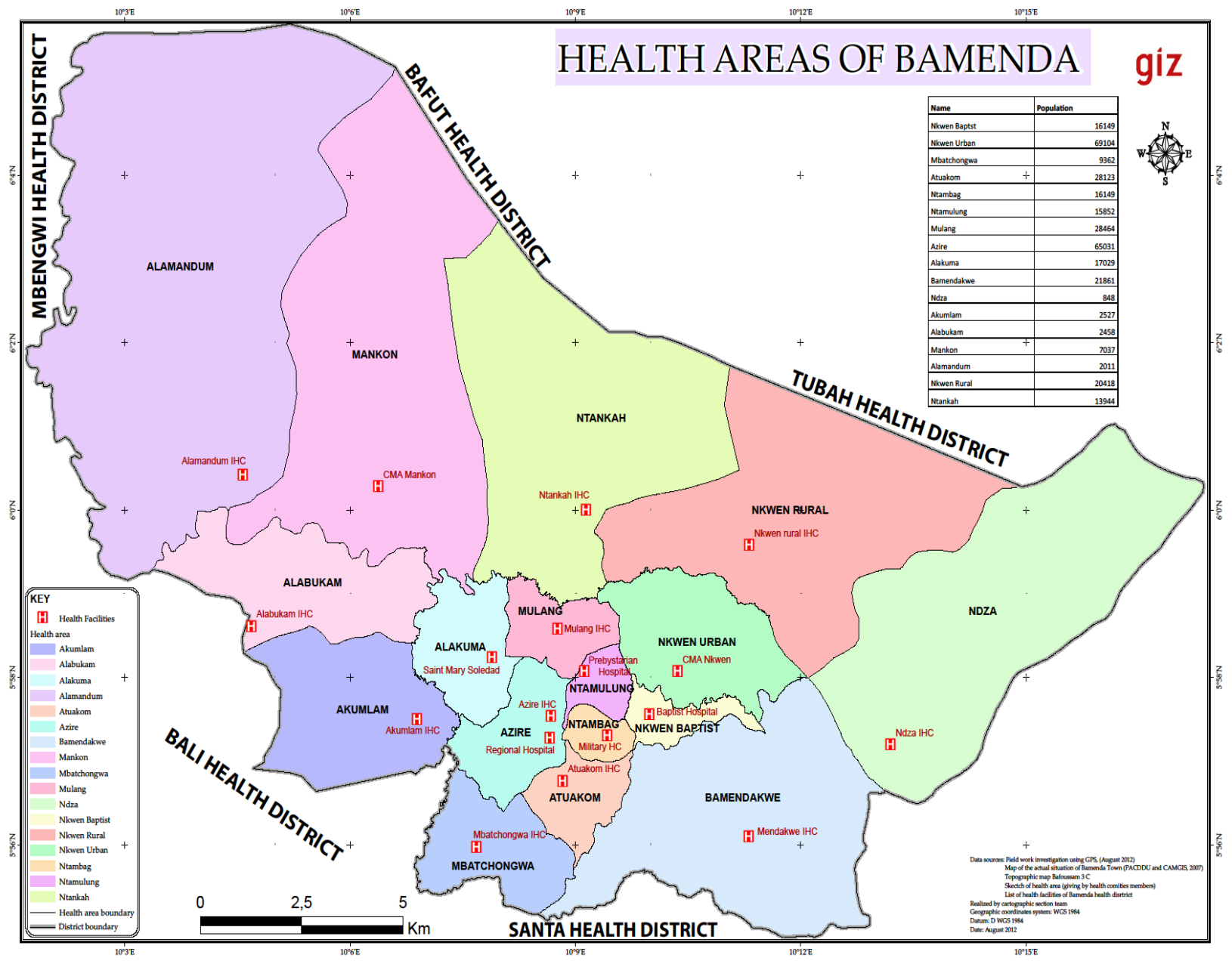

Appendix 1. Map of the Bamenda Health District, indicating the different Health Areas and Integrated Health Centres

\section{REFERENCES}

[1] Hutton G. and Haller L. (2004). Evaluation of the cost and benefit of water and sanitation improvements at the global level. Water Sanitation and Health. Protection of the Human Environment. World Health Organisation.

[2] World Health Organization. (2004). Guidelines for drinking-water quality (Vol. 1). World Health Organization.

[3] Institute Nationale des Statistique (2002) ECAM II: Evolution de la Pauvreté au Cameroun entre 1996 et 2001. Decembre 2002

[4] Ako A. A., Jun S., Eneke G., Takem E., and Yetoh F W., (2010). Access to potable water and sanitation in Cameroon within the context of Millenium Development Goals (MDGS). Water Science and Technology 61(5), 1317 - 1339

[5] MINPLADAT (Ministry of Planning, Programming and Regional Development) 2006 Progress Report on the Implementation of the Poverty Reduction Strategy Paper as of 31 Dec 2005.
[6] WHO (2011). Valuing water, valuing livelihoods. Guidance on social cost-benefit analysis of drinking water interventions, with special reference to small community water supplies. Cameron J., Hunter P., Jagals P., and Pond K., (Eds). London. WHO by IWA Publishing.

[7] Pond K. and Pedley S. (2011). Current Situation in Access to Drinking Water.WHO Valuing Water, Valuing Lives. J. Cameron, P. Hunter, P. Jagals and K. Pond (Eds), 55 - 75.

[8] Kuitcha D., Ndjama J., Tita A. M., Lienou G., Kamgang K. B. V., Ateba B. H., and Ekodeck G. E. (2010). Bacterial Contamination of Water Points of the Upper Mfoundi Watershed Yaoundé Cameroon.African Journal of Microbiology Research, 4(7), 568-574.

[9] Hutton G., Haller L. and J Bartram (2007). Global cost-benefit analysis of water supply and sanitation interventions.Journal of Water 5(4), $481-502$.

[10] WHO/UNICEF (2009). Diarrhoea: Why children are still dying and what can be done?

[11] National Institute of Statistics. 2015. Enquete par grappes à indicateurs multiples (MICS) 2014. Rapport de résults clés. Yaoundé, Cameroun, Institut National de la statistique. 
[12] www.targetmap.com/viewer.aspx?reportld

[13] www.equistinfo/en/dashboard

[14] Bloom D. E., Cafiero E. T., Jane Llopis E., Abrahams Gessels S., Bloom L. R., Fathima S., Feigl A. B., Gaziano T., Mowafi M., Pandya A., Prettner K., Rosenberg L., Seligman B., Stein A. Z., and Weiss, J (2011). The Global Economic Burden of Non-Communicable Diseases. (No.8712) Program on the Global Demography of Aging.

[15] Hutton, G., Water, S., Haller, L., \& World Health Organization. (2004). Evaluation of the costs and benefits of water and sanitation improvements at the global level.
[16] British National Formulary (BNF) (2005). British Medical Association and Royal Pharmaceutical Society of Great Britain. London. BMJ Publishing Group.

[17] O'Neill, Eileen (1999). Early Childhood Education: The Disadvantaged Child: How Early is Early? Irish Journal of Applied Social Studies, 2(1), 2.

[18] Hdr.undp.org/en/countries/profiles/CMR

[19] WHO (2009). WHO guide to identifying the economic consequences of disease and injury.

[20] Organisation for Economic Co-operation and Development (OECD) (2006). Economic valuation of environment health risk to children. OECD, Paris 